\title{
Decision Support Tool for Colombo Canal System Water Quality Monitoring
}

\author{
Nishadi Eriyagama and Niranjanie Ratnayake
}

\begin{abstract}
Pollution of the Colombo Canal System, which is a complex network of open canals and marshes catering to the storm drainage needs of Greater Colombo, has been recognized as a major environmental issue. A Water Quality Monitoring Program is being carried out by SLLR\&DC since 1997, where monthly measurements are recorded at 20 locations for 10 parameters. An attempt was made to integrate the raw data, an analysis of the water quality regime of each location, and a study of its relationship with canal water level and average monthly rainfall, by developing a simple, userfriendly computer package called the Water Quality Monitor (WQM). It will assist the user in decisionmaking, regarding the attainable level of quality for a particular site, and whether that quality level could be reached by varying the canal water level. It also provides a general idea on how much of the target quality is attainable with the dilution and flushing effect of rainfall. A special feature of WQM is the facility provided to analyse the user's own data sets, apart from the built-in Colombo data. This paper describes the rationale, methodology of development and the application of the software package of the 'Water Quality Monitor'.
\end{abstract}

Keywords: Storm drainage, Water quality monitoring, Water quality criteria, Decision support

\section{Introduction}

The city of Colombo houses the main commercial hub of the country with a dense population of approximately 642,000 [17]. The Greater Colombo region encompasses the Colombo city and its immediate suburbs to the North, East and the South, the western boundary being the Indian Ocean. In the context of its low lying terrain, the complex network of interconnected canals and marshes crisscrossing the region, plays a prominent role in ensuring a flood free environment for the masses. The total length of canals is $29.2 \mathrm{~km}$, while it is fed by a catchment area of approximately $99 \mathrm{~km}^{2}$.

The Parliament Lake is the headwater boundary of the Colombo Canal System (Figure 1). It is generally divided into two as the Colombo North system and the Colombo South system. The Colombo North System consists of all canals north of Sri Jayawardenapura Mawatha while the Colombo South system consists of canals south of Sri Jayawardenapura Mawatha (Figure 1). The system has four outlets, three of which, namely, Dehiwala and Wellawatte outfalls and Mutwal Tunnel discharge directly into the sea. The North Lock outlet discharges into the Kelani River. Earlier there used to be a fifth outlet in the form of the circular weir near the old Parliament, facilitating spill from the Beira Lake into the sea. However, the canal system is no longer connected to the Beira Lake, a step taken in order to prevent polluted waters of the northern canals from entering the lake (SLLR\&DC, 2004 [13]). The Mutwal Tunnel is also no longer in operation due to blockage and is almost closed (SLLR\&DC, 2004 [13]). Under dry weather conditions outflow occurs mainly through Dehiwala, Wellawatte and North Lock outlets, while it is reduced to Dehiwala and Wellawatte only during a flood situation, as the North Lock is closed to prevent backwaters of Kelani from entering the canal system.

Other main canals are Kolonnawa Ela , Kotte Ela , Mahawatte Ela, Heen Ela, Torrington canal, Kirillapone canal, Wellawatta canal, Dehiwala canal, Bolgoda canal, Dematagoda canal, St. Sebastian canal, Main Drain and Mutwal Tunnel (Figure 1). The three main retention areas attached to the system are Heen Ela (88 ha), Kotte Lake (97 ha) and Kolonnawa (214 ha) totalling up to approximately 400 ha of low lying marsh lands which play a significant role in detaining excess flood water, so that peak flows are reduced and lag times are increased.

Eng, (Ms.) N. Eriyagama, C. Eng., MIE(SL), B.Sc. Eng. (Hons) (Peradeniya), Water Resources Engineer, International Water Management Institute (IWMI),Battaramulla, Sri Lanka.

Eng. (Prof.)N. Ratnayake, C. Eng., FIE(SL), B.Sc. Eng. (Hons) (Ceylon), M.Eng(Wales),Member, 1WA, Professor ofCivil Engineering, Department of Civil Engineering, University of Moratuwa, Sri Lanka. 


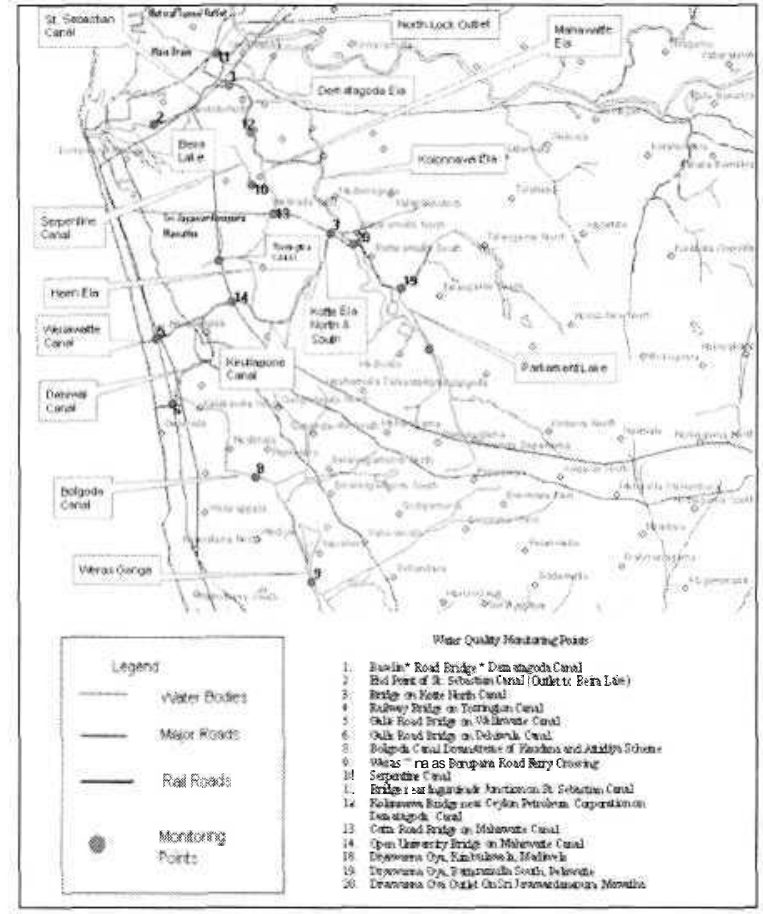

Figure 1 - GeneralLayout of the Colombo Canal System and Location of Water Quality Monitoring Points

\section{Past Studies}

The Sri Lanka Land Reclamation and Development Corporation (SLLR \& DC) launched the Greater Colombo Flood Control and Environment Improvement Project (GCFC \& EIP) in 1993, embarking on a massive exercise of canal clearing, widening, canal lining and other activities, including relocation of shanty communities living along canals. An integral part of the project was a canal water level, discharge and water quality monitoring program, where monthly measurements were taken at 10 locations on the Colombo Canal System, commencing in January 1997. By June 2004 , the number of locations had been increased to 20, with 13 of them lying within the Greater Colombo Area. Table 1 lists the location, and the monitoring period of each location, while Table 2 lists the 10 parameters being measured. The numbers assigned by SLLR\&DC to individual monitoring points, were adopted in the present study, in order to avoid confusion. Out of these locations, only those falling within the Greater Colombo area (all stations except 7, 15,16 and 17) and quality parameters BOD and COD have been included in this application. It is intended to include the rest of the parameters as well in the future.
Although the water quality of the canals was improved to a certain extent as a result of the canal rehabilitation (Nippon Koei et al, 2001 [12]), the emphasis of this project was on addressing inundation of low lying areas in and around Colombo. A detailed "Action Plan for the Control of Pollution in the Greater Colombo Canal System" was prepared under Phase II of GCFC\&EIP in August 2001.

The Colombo Canal System Water Quality Improvement Project is a new project launched by SLLR\&DC, which will implement some of the recommendations made in the above action plan. It focuses on both flood control and water quality improvement, and seeks to provide an immediate solution to the problem of canal

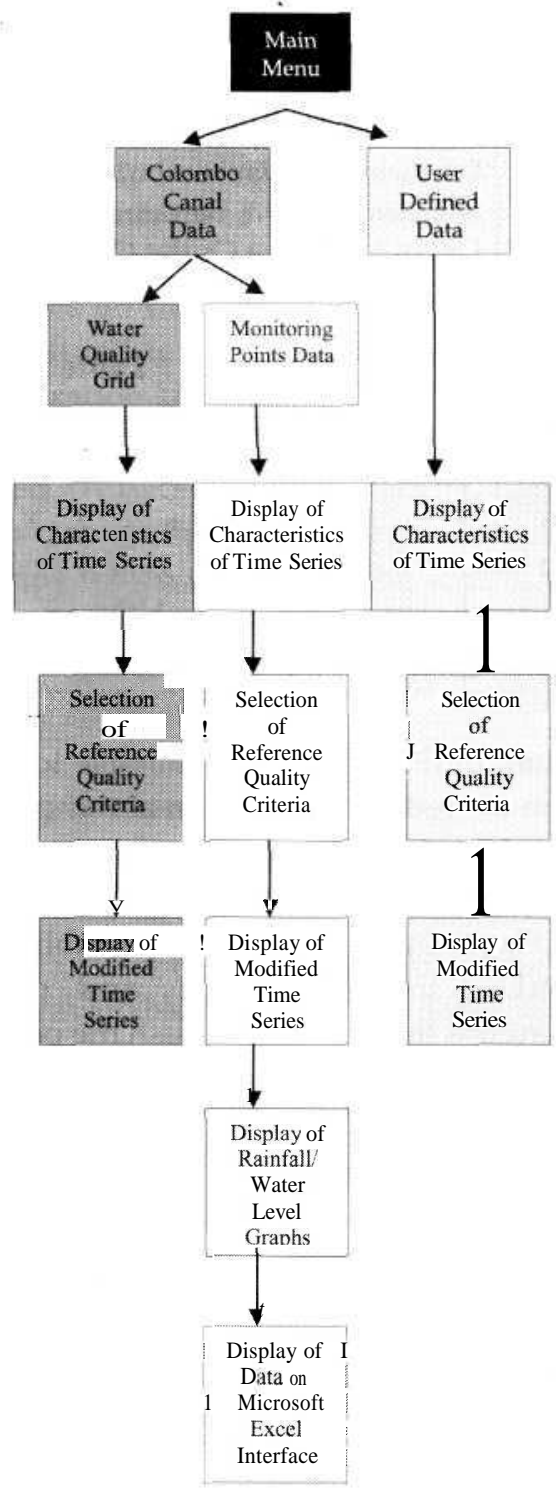

Figure 2 - Application Structure of Water Quality Monitor 
Table 1 - Monitoring Stations and Duration of Water Quality Data

\begin{tabular}{|c|c|c|c|}
\hline \multirow{2}{*}{$\begin{array}{c}\text { Station } \\
\text { No. }\end{array}$} & \multirow[t]{2}{*}{ Name } & \multicolumn{2}{|c|}{ Period } \\
\hline & & From & To \\
\hline 1 & Baseline Road Bridge on Dematagoda Canal & January 1997 & December 1999 \\
\hline 2 & End Point of St. Sebastian Canal (Outlet to Beira Lake) & January 1997 & December 2004 \\
\hline 3 & Parliament Road Bridge on Kotte North Canal & January 1997 & December 2004 \\
\hline 4 & Railway Bridge on Torrington Canal & January 1997 & December 2004 \\
\hline 5 & Galle Road Bridge on Wellawatte Canal & January 1997 & December 2004 \\
\hline 6 & Galle Road Bridge on Dehiwala Canal & January 1997 & December 2004 \\
\hline 7 & Railway Bridge on Lunawa Lake Outfall & January 1997 & December 2004 \\
\hline 8 & $\begin{array}{l}\text { Bolgoda Canal Downstream of Attidiya and } \\
\text { Kawdana Schemes }\end{array}$ & January 1997 & December 2004 \\
\hline 9 & WerasGanga on Borupana Road Ferry Crossing & January 1997 & December 1999 \\
\hline 10 & SerpentineCanal & January 1997 & December 1999 \\
\hline 11 & Bridge near Ingurukade Junction on St. Sebastian Canal & January 2000 & December 2004 \\
\hline 12 & $\begin{array}{l}\text { Kolonnawa Bridge near Ceylon Petroleum Corporation } \\
\text { on Dematagoda Canal }\end{array}$ & January 2000 & December 2004 \\
\hline 13 & Cotta Road Bridge on Mahawatte Canal & January 2000 & December 2004 \\
\hline 14 & Open University Bridge on Kirillapone Canal & January 2000 & December 2004 \\
\hline 15 & $\begin{array}{l}\text { Lunawa Lake, Northern Lake Crossing to } \\
\text { Laksapathiya Road }\end{array}$ & January 2000 & December 2004 \\
\hline 16 & Lunawa Lake, near Doowa Temple, Eastern Side & January 2000 & December 2004 \\
\hline 17 & Lunawa Lake, Lunawa Station Road Crossing & January 2000 & December 2004 \\
\hline 18 & Diyawanna Oya, Kimbulawala, Madiwela & May 2004 & December 2004 \\
\hline 19 & Diyawanna Oya, Battaramulla South, Pelawatte & May 2004 & December 2004 \\
\hline 20 & Diyawanna Oya Outlet On Sri Jayawardanepura Mw. & May 2004 & December 2004 \\
\hline
\end{tabular}

Table 2 - Quality parameters covered

\begin{tabular}{|c|l|c|c|}
\hline No. & Parameter & No. & Parameter \\
\hline $\mathbf{1}$ & BOD 5 $5^{20}$ & 6 & Ammonia \\
2 & COD & 7 & pH \\
3 & DO & 8 & Conductivity \\
4 & Nitrate $\left(\mathrm{NO}_{3}\right)$ & 9 & Turbidity \\
5 & Phosphates & 10 & Temperature \\
\hline
\end{tabular}

pollution, until the more sustainable long term solution of "reducing pollution at the source" is implemented. As part of the project, a hydrodynamic model and water quality model of the Canal System have been established by SLLR\&DC, using Mike 11, and physical interventions that dilute and flush the pollutants out of the system (such as pumping in of Kelani water during dry weather) have been recommended for implementation. While 1-D hydrodynamic modelling has definite advantages in simulation of situations in well regulated linear systems, the application of the water quality module of Mike 11 for a complicated system such as the Colombo Canal System would either require a massive collection of data or produce a very general result which will not be of much use in planning pollution prevention interventions.
With this background in mind, a decision support tool (Water Quality Monitor) was developed both to aid in demarcating a realistic water quality standard for the Colombo Canal System, and to investigate the effect of a natural phenomenon, namely, rainfall, which also dilutes and flushes the pollutants out of the canal system, while raising the water level of the canals. It is also possible to study the effects of the recommended physical interventions by using this simple tool and available water quality, water level and rainfall data, without actually constructing a hydrodynamically driven water quality model.

\section{Water Quality Monitor (WQM)}

WQM may be used by any person having a basic knowledge about water quality and the 
operating system, Microsoft Windows unlike other more complex models. It actually goes one step further in presenting a Water Quality Map of the Greater Colombo area to the user. This map can be used for disseminating information on surface water quality in Colombo even to the general public. Another useful feature is its capability to analyse the user's own set of data, rather than the default Colombo data, by following the same simple steps.

The main objectives of this tool are to:

1. Integrate the available water quality data of the Colombo Canals in an easily accessible database with a user friendly interface

2. Provide decision support on setting criteria for water quality improvement, specifically in the Colombo area, in a simple and understandable manner by studying the total water quality regime of canals.

3. Investigate the possibility of using the canal water level and average monthly rainfall as indicators of water quality and thereby provide decision support on measures to be adopted for improving canal water quality in the Greater Colombo area

4. Supplement other more complex water quality models; And

5. Disseminate Knowledge on canal water quality of the Colombo area, not only to experts but also to anyone having a basic knowledge of water quality

WQM is structured in such a way that broadly it leads in two directions. They are:

1. Default Colombo Data Option

2. User Defined Data Option

However, both routes follow the same analysis procedure. Each option is described in detail in the following paragraphs. The application structure is presented in the flow chart given in Figure2.

\subsection{General Features of WQM}

The rationale described above together with an in-built Microsoft Access database of canal water quality, form the core of the Water Quality Monitor. Keeping in mind its potential use by non-specialists, careful consideration was given to:
- Developing a highly user-friendly environment, so that anyone having a very basic knowledge of water quality could easily grasp the application.

- Enabling access to the default Colombo database through visual examination of the canal system on a geographic map.

- Ensuring that a set of explanations is provided under the 'Help' facility of the package.

- Keeping the software simple and free.

WQM is coded in Visual Basic 2005. A powerful and user-friendly interface which incorporates a programming object called MapWinGIS ActiveX (map) control, acts as the gateway to the default database in addition to providing a visual image of the Colombo Canal System and water quality monitoring points. The MapWinGIS ActiveX control is the core component in MapWindow open source GIS Software (http://www.mapwindow.org/ [19]). This user interface has been developed by overlaying several raster and vector GIS coverages on the map control. Alternatively, a user-defined text file containing a parameter concentration time series (for BOD and COD only at present) for a point of interest may also be used. A two-fold 'Help' facility, namely the "Help" tab on the Menu Bar, and step by step help tips which appear on the screen, provide users with basic background information about the package as well as guidance for proceeding with the application.

\subsection{Application Procedure}

\section{Step 1: Select Data Source}

The Data tab of the Main Menu displays the two options available for selecting a data source. The "Colombo Canal Data" option provides access to the in-built water quality database described earlier. A user may select either the "Monitoring Points" or the "Water Quality Grid" option to access data directly from monitoring points themselves or from a "Quality Region". An interactive map of Sri Lanka will be loaded onto the screen once either of the above options is selected. Facilities are also provided for zooming, panning and selecting points on the map. Progressive zooming will expose individual "Quality 
Regions" of the Water Quality Grid and several layers of GIS shape files presenting a visual image of the canal system. In addition, geographic coordinates of the cursor position are displayed as the cursor moves on the screen. The extent of details exposed on the map depends on the current zoom level (Figure 3).

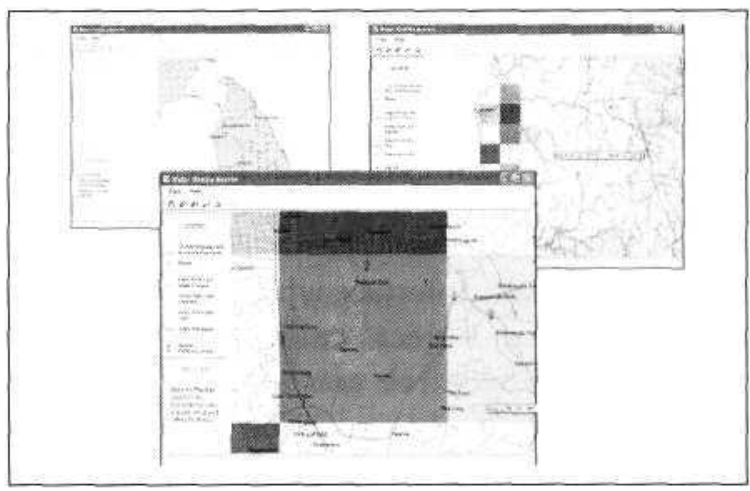

Figure 3 - The Main Screen with different zoom levels

The "Monitoring Points" option provides access to the historical water quality data of the 13 monitoring points lying within the Greater Colombo area. The interactive map enables the user to visualize the exact location of each monitoring point relative to other prominent features in the area. By selecting a specific quality parameter and a monitoring point (from a dropdown menu), a monthly time series of concentration values of that particular parameter at the selected point will be accessed from the database, and its main characteristics displayed in a new screen (Figure 4). Once the "Water Quality Grid" option is selected, it is possible to access the time series for a particular parameter from one of the "quality regions" by clicking on any one of them. This is a GIS grid corresponding to the selected parameter, which has been constructed by considering December 2004 data of all monitoring points. The higher the colour, the lower the level of quality. Canal segments within each cell will have the same quality level. Monthly grids were constructed for total duration of data by using the ArcGIS software. Thus, each grid cell has a time series of its own. In essence, this option presents the user with a canal water quality map of Colombo. The characteristics of the accessed data will be displayed in the new screen as shown in Fig 4.

The Water Quality Grid was constructed in order to establish benchmarks for each region in the Greater Colombo Area with respect to canal water quality as far as possible, so that the locations where urgent attention is needed may be recognized. Although data is available only within the canals themselves, a quality grid covering the entire region was constructed in order to highlight the significance of influence of each canal segment. The cell size was selected so as to cover the entire region; as such the cells themselves by no means represent the exact boundary or the extent of the area of influence. The Water Quality Grid will also serve as a datum for comparing future water quality improvements. Furthermore, the grid may be used as a tool for disseminating information on canal water quality of Colombo to the general public. At present, only the grid for BOD has been added to the application, while it is intended to add the corresponding grids for other parameters later.

The "User Defined File" option provides a user with a facility to analyse his/her own quality time series. The structure and the format of this input file is described in the "Help" facility of the software. General characteristics of the time series selected are then displayed similarly to the first option (Figure 4).

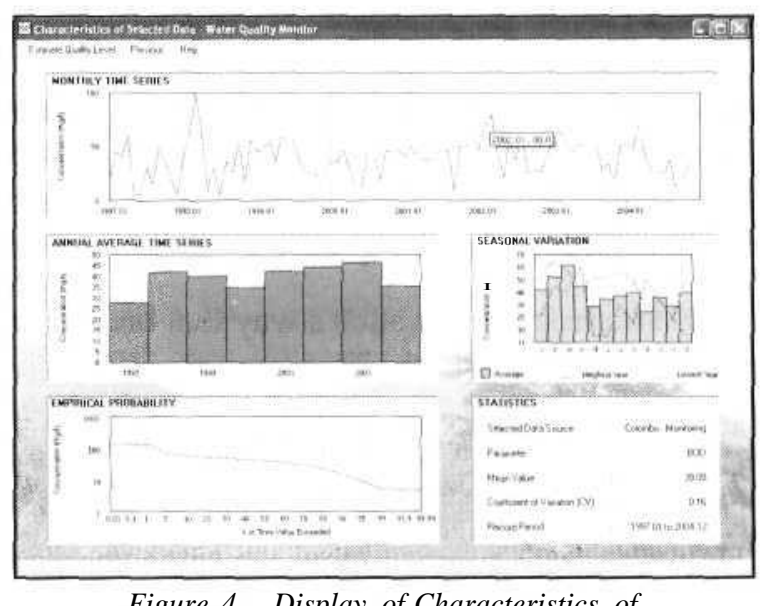

Figure 4 - Display of Characteristics of Selected Water Quality Data

\section{Step 2 : Display of Characteristics of Time Series Data}

The displayed characteristics include: original monthly time series, annual average time series, monthly (seasonal) distributions (long-term average as well as for the years with the "worst" average quality and the "best" average quality in the available record), a period of record Probability Distribution Curve (PDC) and some 
basic statistics (Figure 4). Selecting the option "Estimate Quality Level" on the menu of this screen leads the user to the next step in the application.

\section{Step 3 : Selection of Appropriate Quality Level to be adopted}

The quality level selection procedure is intended as a means of examining and comparing the present state of quality at a particular site with accepted standards. Considering the highly polluted state of some of the Colombo canals, it may not be very realistic to achieve the ambient water quality criteria proposed by the CEA, in the immediate future. Therefore, this procedure allows the user to select an achievable level of quality by considering the site's "actual" quality regime by establishment of a cumulative probability distribution function for each measured parameter, by plotting its concentration against the empirical probability (percentage) of excedence (Fig 5). The calculation procedure is adopted for water quality from an Environmental Flow Requirement calculation methodology developed by Smakhtin and Anputhas [14] and a Global Environmental Flow Calculator Software developed by Smakhtin and Eriyagama [15].

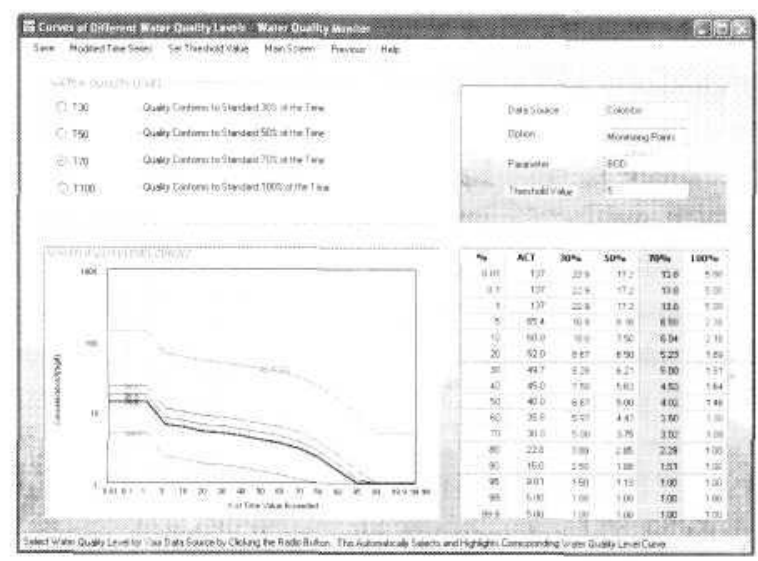

Figure 5 - The reference PDC, QLCs and the highlighted $70 \%$ quality level curve and corresponding values on table when $T 70$ is selected

The available historical water quality time series data was assumed to represent the "actual" or Reference Condition of the Colombo Canal System. At some locations, the actual quality is observed to exceed the interim ambient water quality standard of $3.0 \mathrm{mg} / \mathrm{l}$ BOD almost $100 \%$ of the time.
Apart from the "actual" or reference curve, WQM provides the facility to construct another set of curves, called Quality Level Curves (QLC), to visualize the scenarios of meeting the water quality standards $30 \%, 50 \%, 70 \%$ and $100 \%$ of the time, by shifting the actual curve vertically downwards (Figure 5). Here the assumption is that concentrations having equivalent percentage probabilities of excedence on both the reference curve and selected QLC (which represents the condition after implementing pollution control interventions) will occur on the same month. This range of choices is provided since $100 \%$ conformity may not be realistic for some canals, at least at the present point of time. The most appropriate QLC for the location in question may be selected by the user considering all relevant scenarios. This requires expert judgment on its present and desired water quality. For example, for parameter BOD, if the $70 \%$ curve is selected, the BOD concentration at this particular location will be equal to or below the accepted value $70 \%$ of the time, while it will be above the accepted value $30 \%$ of the time.

In addition to plotting the PDCs for Reference condition and each Quality Level, WQM tabulates the concentration values corresponding to the 17 fixed percentage points: $0.01,0.1,1,5,10,20,30,40,50,60,70,80,90,95$, $99,99.9$ and $99.99 \%$ - with a separate column for each Quality Level. The user can select the most appropriate or realistic Quality Level for the site in question (Figure 5). A facility for writing a complete table of all curves or the selected quality column alone, into a text file is also provided. It is also possible to repeat the above procedure with a different quality threshold (concentration value) by selecting the "Set Threshold Value" menu item on this screen, so that a realistic quality threshold and an appropriate Quality Level for the site in question may be formulated.

\section{Step 4: Display Reference and Modified Monthly Concentration Time Series}

Clicking on "Modified Time Series" menu item on the previous screen activates the generation of monthly concentration time series from selected QLC and immediate subsequent display of the reference and modified monthly concentration time series (Figure 6). 


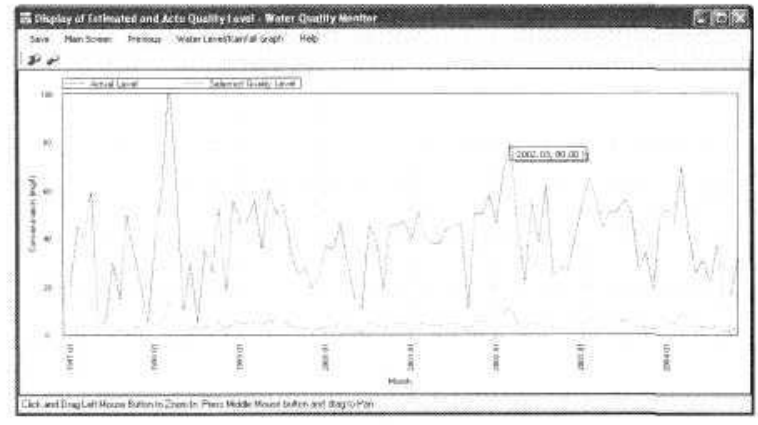

Figure 6 - Graph showing actual and modified time series data

This interactive graphical display has been created by using a free component called ZedGraph (http://zedgraph.org/wiki/ index.php?title=Main_Page). Tools are provided for panning and zooming on the graphs and displaying actual data values at current cursor position. In addition, reference ("actual") parameter concentrations and modified concentrations corresponding to the 17 percentage points may be written into a text file.

\section{Step 5: Water Level/Rainfall Relationship and Excel Interface}

The next screen maps out the relationship between the canal water quality (parameter concentration) and the water level as well as that between water quality and average monthly rainfall. However, this facility is available only if the Monitoring Points option was selected at the Main Screen (Figure 7).

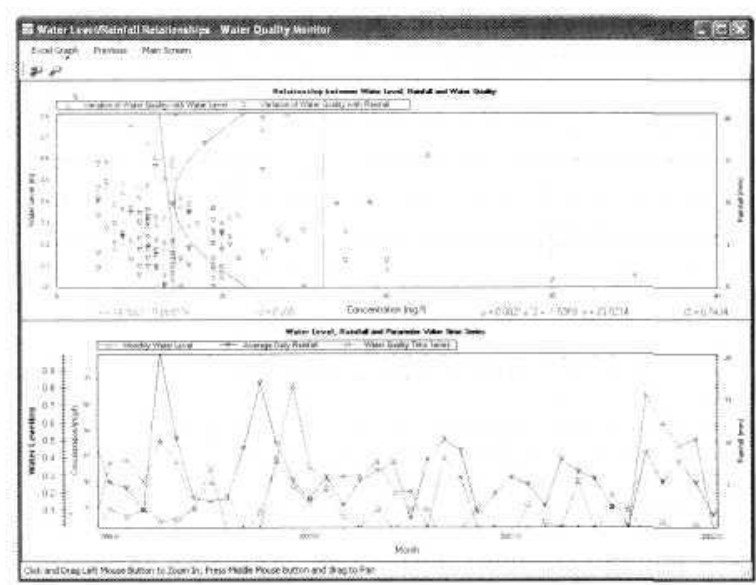

Figure 7 - The Graphs Showing Water Quality, Water Level and Rainfall Relationships

The top graph plots theapproximated curves for the two relationships (Figure 7) using simple linear regression (least squares method), while the equation of the curve and the goodness of fit statistics (mean square error - r2) are also displayed. Both curves have a common $\mathrm{X}$ axis while the $Y$ axis on the left shows the water level and the $\mathrm{Y}$ axis on the right shows the average daily rainfall. The red line represents the maximum concentration of the parameter on the modified time series. The intersection of this line, and the water level (green) curve indicates the water level at which the above concentration is present. If the water level and rainfall curves are to the far left of the red curve, it indicates that selection of a better quality level may be possible. On the other hand, if they are to the far right of this curve, then a lower quality level will have to be contemplated.

However, the success of this exercise depends on obtaining good relationships between water level and water quality, and average monthly rainfall and water quality. Hence an Excel interface is provided, so that the data sets may be examined for outliers etc. and a better relationship may be obtained by excluding the bad quality data, while the trend line type may also be changed to obtain a better fit (Figure 8).

\section{Results and Discussion}

It is evident that in the Water Quality Grid for BOD, the cell bounded by the areas Meetotamulla, Wellampitiya, Megoda Kolonnawa, Gotatuwa, Madinnagoda, Cotta Road, Borella and Kuppiyawatta (or the cell including Mahawatte Ela, Serpentine Canal, southern part of Dematagoda Canal and Northern part of Kolonnawa Ela) has the worst quality with respect to organic pollution (BOD). It has an average monthly BOD level of $52 \mathrm{mg} / 1$ for the period from January 1997 to December 2004 with a coefficient of variation of 0.28 . The fiftieth percentile BOD level is $34 \mathrm{mg} / \mathrm{l}$, while it exceeds $22 \mathrm{mg} / 1$ seventy percent of the time and $3 \mathrm{mg} / 1 \mathrm{100 \%}$ of the time. Thus it seems unrealistic to expect the BOD level to be maintained at $3 \mathrm{mg} / 1$ (present ambient standard) $100 \%$ of the time, in the short or medium term. It would be more realistic, for example, to aim at maintaining the BOD at below $34 \mathrm{mg} / 1$, which is the fiftieth percentile value, over the entire period considered. According to the water level/BOD relationship obtained for station 10 (which lies within this cell), it can be seen that the above quality can be achieved by maintaining its water level at $2.0 \mathrm{~m}$. It is also possible to see during which periods in 


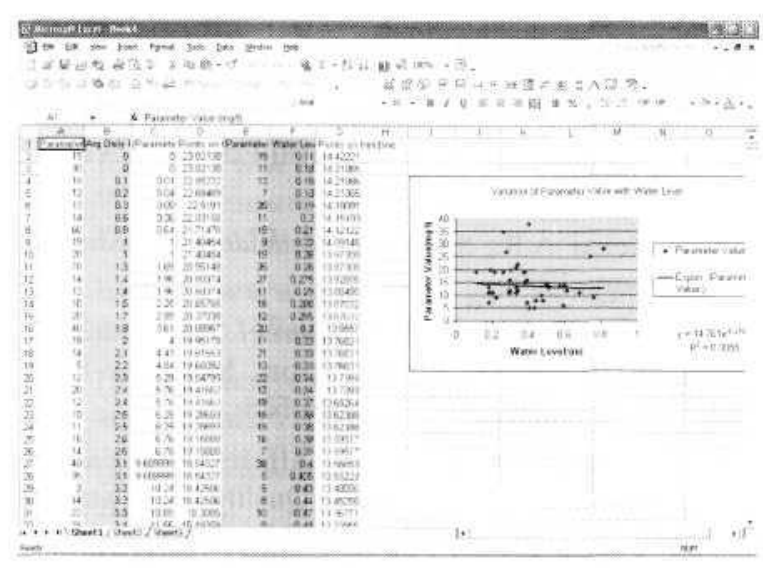

Figure 8 - The Microsoft Excel Interface

the year the water level is likely to be less than this value, and therefore, the periods of the year during which the authorities have to be alert about deteriorating water quality. Thus, the interventions needed to achieve the stated quality can be planned. However, when considering this particular point, $2.0 \mathrm{~m}$ water level implies a flood situation. ie., at present pollution levels, even a $34 \mathrm{mg} / 1$ standard cannot be achieved only by increasing the canal water level. Therefore, urgent action is necessary to cut off at least the major sources of pollution within this area.

The grid cell bounded by the areas Pita Kotte, Etul Kotte, Madinnagoda, Kalapaluwawa, Koswatta, Talangama South and Madiwela (or the cell including Parliament Lake, Kotte Ela North and the southernmost part of Kolonnawa Ela) has the highest quality when considering organic pollution. It has an average monthly BOD level of 11 for the period considered with a coefficient of variation of 0.21 . The fiftieth percentile BOD level is $8 \mathrm{mg} / 1$, while it exceeds $6 \mathrm{mg} / 1$ seventy percent of the time and $3 \mathrm{mg} / 1$ ninety five percent of the time.

When considering the two main sections of the canal system, the cells in the Northern System have an average BOD level of 39 for the period considered, while that of the cells in the Southern System is 21. Out of the individual monitoring points, Monitoring Point 10 on Serpentine Canal has the highest average BOD level $(93 \mathrm{mg} / 1)$ with a coefficient of variation of 0.16 , while it also has the highest average COD level of $134 \mathrm{mg} / 1$ with a coefficient of variation of 0.24 . Therefore, undoubtedly the Northern System is more polluted than the Southern System. This may be explained by the fact that the canals (especially Serpentine Canal) in the northern system, are exposed to many industrial and domestic sources having high levels of pollution (Nippon Koei, 2001 [12]). On the other hand, the Southern System has the benefit of being connected to many large water bodies and marshes (Parliament Lake, Kotte Marsh, Heen Marsh and Weras Ganga) which help to intercept and dilute the pollution entering canals. The Kalapaluwawa Marsh is the only Marsh area connected to the Northern System. Therefore, the application also highlights the role that water bodies and wetlands play as natural buffers of pollution.

The first priority in a long term solution to the problem of pollution of Colombo Canals should be to disconnect direct pollution sources within the most polluted cell in the Water Quality grid (cell including Mahawatte Ela, Serpentine Canal, southern part of Dematagoda Canal and Northern part of Kolonnawa Ela) by introducing wastewater treatment, solid waste bins and proper sewage treatment facilities. If the level of pollution in this area is lowered, the water quality of the rest of the Northern System will also be dramatically improved.

The BOD and COD levels of all monitoring points demonstrate an inverse relationship with both water level and rainfall. Station 10 on Serpentine Canal, which incidentally appears to have the worst quality, shows the best correlation with water level for both BOD and COD with mean square error values of 0.5041 and 0.8037 respectively. Station 1 (Baseline road bridge on Dematagoda Canal) has the best correlation with rainfall for both BOD and COD. It also shows the second best $\mathrm{COD} /$ water level correlation. As expected, the data show better correlation with the water level than with the monthly average rainfall. Both Stations 1 and 10 are in the Northern Canal System, which is also the most severely polluted section within the Greater Colombo region. Hence, these may be used as benchmark points for monitoring the water quality of the Colombo Canal System, considering the water level as an indicator.

\section{Conclusion}

This paper describes a simple decision support tool, capitalising on existing water quality, water level and rainfall data, which can be used 
for setting criteria for achievable improvements to water quality in the Colombo Canal System. The graphical outputs of the water quality time series, seasonal variations, water quality grid, probability curves and rainfall/water level relationships provided by the tool help plan improvement measures with a sound understanding of the prevalent situation. It can also be used for visualising the present and achievable quality levels for any other site where time series water quality data is available.

The water quality grid helps to identify the areas in the Colombo region that need urgent attention, with respect to pollution control measures such as control of point sources, solid waste management, dredging and flushing of the canals etc. Thus, the investments on interventions can be made on a more rational basis. The water level and rainfall relationships with water quality, provided by the tool, also help make more informed decisions on planning the necessary interventions to maintain the canal water quality at the set criteria throughout the year, particularly at the locations where the relationships show good correlations.

However, it is accepted that the method described in the paper is not an ultimate solution to solving the problem of pollution of the Colombo Canal System, nor is it intended to replace the more complex hydrodynamic models, but rather supplement them. It is hoped that the WQM will help raise awareness on diverse avenues of investigation in finding solutions to the complex problem of canal pollution.

\section{Acknowledgements}

The water quality and water level data used in the default database has been provided by the Sri Lanka Land Reclamation and Development Corporation (SLLR\&DC), while the rainfall data were obtained from the Meteorological Department of Sri Lanka. The GIS data has been provided by ESRI and the IWMI RS/GIS Data Storehouse. The MapWinGis Active-X control used in the software has been developed by the MapWindow Open Source Team led by Dr. Daniel P. Ames of Idaho State University (USA), while Zedgraph (the interactive graphing component) has been produced by John Champion (USA).

\section{References}

1. Aczel, A. D., Sounderpandian, J., Business Statistics, TATA - McGraw - Hill Edition, TATA McGraw - Hill, 2002

2. Chandekar A.R., Statistical Methods, S. Chand \& Company, 1994

3. Chow, V. T., Open-Channel Hydraulics, International Student Edition, McGraw-Hill Kogakusha Ltd., 1959, pp. 525-528

4. Danish Ministry of Foreign Affairs, Appraisal of Colombo Canal System - Water Quality Improvement Project, Sri Lanka - Final Report, May 2005

5. Gray, N. F., Water Technology, ButterworthHeinemann, 1999

6. Hammer, M. J., Hammer, M. J. Jr., Water and Wastewater Technology, 3rd ed., Prentice-Hall of India, 1998

7. Inc. Metcalf \& Eddy, Tchobanoglous, G., Burton, F. L., Stensel, H. D., Wastewater Engineering Treatment and Reuse, McGraw-Hill, 2002

8. Ministry of Foreign Affairs of Denmark, Technical Assistance for Preparation and Tendering of Colombo Canal System Water Quality Improvement Project, February 2006

9. Nippon Koei Co. Ltd., The Study on Storm Water Drainage Plan for the Colombo Metropolitan Region, funded by JICA, Volumes I through V, 2003

10. Nippon Koei Co. Ltd., WS Atkins International Ltd, Resource Development Consultants Ltd., Greater Colombo Canal and Drainage System Rehabilitation Project: Design Main Report, 1992

11. Nippon Koei Company, LTd., WS Atkins International Ltd., Engineering Consultants Ltd., Land Reclamation and Development Co., Ltd., Specific Action Plan for the Control of Solid Waste Disposal into the St. Sebastian Canal and Main Drain, September 2000

12. Nippon Koei Company, LTd., WS Atkins International Ltd., Engineering Consultants Ltd., Land Reclamation and Development Co., Ltd., Action Planfor the Contro; of Pollution in the Greater Colombo Canal System, August 2001

13. Sri Lanka Land Reclamation \& Development Corporation (SLLR\&DC), Colombo Canal System Water Quality Improvement Project, December 2004

14. Boyer, J. N., Sterling, P., Jones, R. D., "Maximizing Information from a Water Quality Monitoring Network through Visualization Techniques", Estuarine, Coastal and Shelf Science, Vol. 50, pp. 3948,2000

15. Neal, C., House W. A., Jarvie H. P., Neal, M., Hill, L., Wickham, H. "The water quality of the River Dunn and the Kennet and Avon Canal," Journal of Hydrology, Vol 330, pp. 155 - 170, 2006

16. Smakhtin, V., Anputhas, M. "An Assessment of Environmental Flow Requirements of Indian River Basins," Research Report 107, International Water Management Institute, Colombo, Sri Lanka 
17. Smakhtin, V., Eriyagama, N., "Global Environmental Flow Calculator", International Water Management Institute, 2007

18. http://www.dhigroup.com/Software/ WaterResources/MIKE11.aspx, Visited on December 10, 2006

19. http://www.statistics.gov.lk/PopHouSat/ index.asp, Visited on December 10, 2006

20. (http://www.epa.gov/athens/wwqtsc/html/ wasp.html), Visited in November, 2006

21. (http://www.mapwindow.org/), Visited in June, 2006

22. (http://www.codeproject.com/csharp/ ZedGraph.asp), Visited in August, 2006 